\title{
Article \\ A Novel Singleton Giant Phage Yong-XC31 Lytic to the Pyropia Pathogen Vibrio mediterranei
}

\author{
Lihua Xu ${ }^{1,2,+}$, Dengfeng Li ${ }^{1, *}{ }^{\dagger}$, Yigang Tong ${ }^{3, *}$, Jing Fang ${ }^{4}$, Rui Yang ${ }^{1}$, Weinan Qin ${ }^{1}$, Wei Lin ${ }^{1}$, Lingtin Pan ${ }^{1}$ \\ and Wencai Liu ${ }^{1}$ \\ 1 Zhejiang Key Laboratory of Marine Biotechnology, Ningbo University, Ningbo 315832, China; \\ xulihua202102@163.com (L.X.); yangrui@nbu.edu.cn (R.Y.); 1811091046@nbu.edu.cn (W.Q.); \\ weilin0577@163.com (W.L.); 1911091090@nbu.edu.cn (L.P.); liuwencai103@163.com (W.L.) \\ 2 Collage of Food and Pharmaceutical Sciences, Ningbo University, Ningbo 315832, China \\ 3 School of Life Science and Technology, Beijing University of Chemical Technology, Beijing 100029, China \\ 4 Ocean College, Qinzhou University, Qinzhou 535099, China; fj19891101@gmail.com \\ * $\quad$ Correspondence: lidengfeng@nbu.edu.cn (D.L.); tong.yigang@gmail.com (Y.T.); Tel.: +86-13819823176 (D.L.) \\ $\dagger$ These authors contributed equally to this work.
}

Citation: Xu, L.; Li, D.; Tong, Y.; Fang, J.; Yang, R.; Qin, W.; Lin, W.; Pan, L.; Liu, W. A Novel Singleton Giant Phage Yong-XC31 Lytic to the Pyropia Pathogen Vibrio mediterranei. Appl. Sci. 2021, 11, 1602. https:// doi.org/10.3390/app11041602

Academic Editor: Marco F. L. Lemos Received: 6 January 2021

Accepted: 5 February 2021

Published: 10 February 2021

Publisher's Note: MDPI stays neutra with regard to jurisdictional claims in published maps and institutional affiliations.

Copyright: (C) 2021 by the authors. Licensee MDPI, Basel, Switzerland. This article is an open access article distributed under the terms and conditions of the Creative Commons Attribution (CC BY) license (https:// creativecommons.org/licenses/by/ $4.0 /)$.

\begin{abstract}
Vibrio mediterranei 117-T6 is extensively pathogenic to several Pyropia species, leading to the death of conchocelis. In this study, the first V. mediterranei phage (named Vibrio phage Yong-XC31, abbreviated as Yong-XC31) was isolated. Yong-XC31 is a giant phage containing an icosahedral head about $113 \mathrm{~nm}$ in diameter and a contractible tail about $219 \mathrm{~nm}$ in length. The latent period of Yong-XC31 is $30 \mathrm{~min}$, and burst size is 64,227 . Adsorption rate of Yong-XC31 to V. mediterranei 117-T6 can reach $93.8 \%$ in $2 \mathrm{~min}$. The phage genome consisted of a linear, double-stranded 290,532 bp DNA molecule with a $\mathrm{G}+\mathrm{C}$ content of $45.87 \%$. Bioinformatic analyses predicted 318 open reading frames (ORFs), 80 of which had no similarity to protein sequences in current (26 January 2021) public databases. Yong-XC31 shared the highest pair-wise average nucleotide identity (ANI) value of $58.65 \%$ (below the $\geq 95 \%$ boundary to define a species) and the highest nucleotide sequence similarity of $11.71 \%$ (below the $>50 \%$ boundary to define a genus) with the closest related phage. In the proteomic tree based on genome-wide sequence similarities, Yong-XC31 and three unclassified giant phages clustered in a monophyletic clade independently between the family Drexlerviridae and Herelleviridae. Results demonstrated Yong-XC31 as a new evolutionary lineage of phage. We propose a new phage family in Caudovirales order. This study provides new insights and fundamental data for the study and application of giant phages.
\end{abstract}

Keywords: Vibrio mediterranei; giant phage; complete genome

\section{Introduction}

Vibrios are ubiquitous in marine ecosystems living as well-described pathogens of aquatic fauna, for example, Vibrio anguillarum, Vibrio harveyi, Vibrio coralliilyticus and Vibrio aestuarianus [1-4]. Vibrio mediterranei is a potential emerging pathogen of marine animals such as corals and scallops [5,6]. V. mediterranei 117-T6 (CGMCC1.16311) was isolated from the bleached shell-born conchocelis of Pyropia yezoensis and was pathogenic to the conchocelis of several Pyropia species, including P. yezoensis [7,8]. Pyropia culture has a long history in China, but there are no effective prevention and control measures for bacterial diseases, which seriously affect the economic income of farmers and the healthy and sustainable development of Pyropia industry [8,9]. Global warming has caused an increase in sea surface temperature that has undoubtedly led to the unseasonal outbreaks of Vibrios as well as their increased abundance and virulence in marine environments and aquaculture $[10,11]$. Therefore, there are a growing need for effective methods for managing bacterial infections. 
Viruses, in particular bacteriophages are the most abundant biological entities in the oceans, showing an extremely high, uncharted diversity [12]. The potential of viruses as therapeutic agents to treat infectious diseases has been known for a long time, and they are considered to be important agents and resources as a solution to antibiotic resistance [13]. The phages with double-stranded (ds) DNA genomes larger than $200 \mathrm{kbp}$ are defined as giant or "jumbo" bacteriophages [14]. Giant bacteriophages commonly contain many genes that do not exist in the small genome bacteriophages. For example, some giant phages have several paralogous genes for DNA polymerase and RNA polymerase (RNAP). Importantly, the proteins encoded by these additional genes may replace the function of the host proteins, thereby reducing the dependence of giant phages on their bacterial hosts [15]. In addition, many genes in giant phages are interpreted as coding hypothetical proteins which are not found in small phages, and their biological features are understudied [14]. These genes may be a new resource of proteins for industrial, agricultural, or medical applications in the future [16-19]. However, large phages are not commonly isolated. Limited mobility on semi-solid plates, which prevented formation of visible plaques, may be the possible reason for the rare isolation of giant phage $[15,20]$. A centrifugal force that is too high, in the centrifugation to remove bacteria and protists, may also be a reason.

In recent years, bacteriophages have been increasingly applied for disease prevention and control in aquaculture [21-23]. To mine potential marine application resources for disease control of Pyropia vibriosis, the first $V$. mediterranei phage, named Vibrio phage Yong-XC31 (abbreviated as Yong-XC31), was isolated from the coastal water of Meishan island $\left(29^{\circ} 46.989 \mathrm{~N} 121^{\circ} 57.516 \mathrm{E}\right)$, Ningbo, China. Characteristics and the complete genome of the phage were analyzed. Vibrio phage Yong-XC31 is a giant phage presenting a new evolutionary lineage of phage.

\section{Materials and Methods}

\subsection{Bacterial Strains and Culture Conditions}

Vibrio mediterranei strain 117-T6 (China General Microbiological Culture Collection, CGMCC 1.16311) was provided by the Key Laboratory of Marine Biotechnology of Ningbo University [7,8]. V. mediterranei 117-T6 was cultured in NB seawater medium (peptone $10 \mathrm{~g}$, beef extract $3 \mathrm{~g}$, make final volume up to $1 \mathrm{~L}$ with filtered seawater, $\mathrm{pH} 7.2$ ) at $29^{\circ} \mathrm{C}$ with shaking at $180 \mathrm{rpm}$.

\subsection{Antibiotic Susceptibility Test}

Antibiotic susceptibility test was performed using antibiological susceptibility discs (Hangzhou Binhe Microorganism Reagent. Co., Ltd., Hangzhou, China), according to the instructions and following the standard of the Clinical \& Laboratory Standards Institute (CLSI). 17 types of antibiotic disks were used as follows: penicillin G (6 $\mathrm{gg})$, amoxicillin $(10 \mu \mathrm{g})$, cephalexin $(30 \mu \mathrm{g})$, kanamycin $(30 \mu \mathrm{g})$, gentamicin $(10 \mu \mathrm{g})$, tobramycin $(10 \mu \mathrm{g})$, azithromycin $(15 \mu \mathrm{g})$, aboren $(30 \mu \mathrm{g})$, chloramphenicol $(30 \mu \mathrm{g})$, ofloxacin $(5 \mu \mathrm{g})$, tetracycline $(30 \mu \mathrm{g})$, doxycycline $(30 \mu \mathrm{g})$, rifampin $(5 \mu \mathrm{g})$, trimethoprim/ sulphamethaxazole $(1.25 / 23.75 \mu \mathrm{g})$, vancomycin $(30 \mu \mathrm{g})$, polymyxin $(30 \mu \mathrm{g})$ and clindamycin $(2 \mu \mathrm{g})$. Fresh $\log$ phase $V$. mediterranei 117-T6 cultures were spread by sterial swab on Muller-Hinton agar medium, dried at room temperature (about $5 \mathrm{~min}$ ). Antibiotic discs were then placed on the surface of the medium with triplicates. The plates were incubated at $29^{\circ} \mathrm{C}$ for 16 to $18 \mathrm{~h}$. The diameters of the inhibition zones formed were measured.

\subsection{Phage Isolation and Morphological Observation}

The surface seawater samples used for bacteriophage separation were collected from the seaside of Meishan island ( $29^{\circ} 46.989$ N 121 57.516 E), Ningbo, China on 31 July 2018. The water samples were placed in an ice box and immediately brought back to the laboratory for treatment. After centrifugation at $10,000 \times g$ for $10 \mathrm{~min}$, each $80 \mathrm{~mL}$ supernatant was mixed with $40 \mathrm{~mL}$ of $3 \times \mathrm{NB}$ seawater medium and $2 \mathrm{~mL} V$. mediterranei $117-\mathrm{T} 6$ of $\log$ phase $\left(\mathrm{OD} 600 \approx 0.6,1.91 \times 10^{9} \mathrm{CFU} / \mathrm{mL}\right)$. The mixtures were cultured at $29{ }^{\circ} \mathrm{C}$ with shak- 
ing speed of $180 \mathrm{rpm}$ for $3-4 \mathrm{~h}$ to enrich the phages, and then centrifuged at $10,000 \times g$ for $10 \mathrm{~min}$. The supernatants were filtered through $0.45 \mu \mathrm{m}$ pore-size filters. Pure phage strain was obtained by three serial single-plaque isolation using the conventional double-layer agar method [24] employing V. mediterranei strain 117-T6 as the host. The bacteriophage was negatively stained with $3 \%$ uranium acetate for $20 \mathrm{~s}$ and observed under transmission electron microscope (Hitachi H-7650, Tokyo, Japan).

\subsection{Thermal and $p H$ Stability}

Thermal stability was assessed by exposing aliquots of phage suspension $\left(7.5 \times 10^{7} \mathrm{PFU} / \mathrm{mL}\right.$, $1 \mathrm{~mL}$, in triplicates) to various temperatures $\left(40,50,60\right.$ and $\left.70{ }^{\circ} \mathrm{C}\right)$ for $30,60,90,120,150$ and $180 \mathrm{~min}$, respectively. To test the $\mathrm{pH}$ stability of Yong-XC31, aliquots of phage suspension $\left(7.5 \times 10^{7} \mathrm{PFU} / \mathrm{mL}, 1 \mathrm{~mL}\right.$, in triplicates) were adjusted using $\mathrm{NaOH}$ or $\mathrm{HCl}$ to various $\mathrm{pHs}$ (2-12), withdrawn for $2 \mathrm{~h}$ at $29^{\circ} \mathrm{C}$. Titers of the treated and untreated control samples were measured using the double-layer plate method. The experiment was repeated three times.

\subsection{MOI Selection Experiments and Adsorption Test}

In multiplicities of infection (MOIs) selection experiments, $7.5 \times 10^{5} \mathrm{PFU}$ of YongXC31 was mixed with a set of serial dilutions of $117-\mathrm{T} 6$ cell suspensions $\left(7.5 \times 10^{4}\right.$ to $7.5 \times 10^{8} \mathrm{CFU}$ ) at MOIs of $0.001,0.01,0.1,1$ and 10, respectively, with triplicates. After $10 \mathrm{~min}$ of adsorption at $29^{\circ} \mathrm{C}$, the mixtures were centrifuged at $10,000 \times \mathrm{g}$ for $10 \mathrm{~min}$. The precipitates were suspended in $5 \mathrm{~mL} \mathrm{NB}$ seawater medium and incubated for $3 \mathrm{~h}$ at $29^{\circ} \mathrm{C}$ with shaking speed of $180 \mathrm{rpm}$. Titers in the supernatant of the lysates were measured by using the double-layer agar plate method. The experiment was repeated three times. The MOI with the highest phage production was considered as the optimal one.

To evaluate optimum adsorption time, the phage was mixed with 117-T6 at the optimal MOI of 0.001 (phage-to-bacterium ratio $=7.5 \times 10^{5} \mathrm{PFU} / 7.5 \times 10^{8} \mathrm{CFU}$ ) with triplicate and incubated at $29^{\circ} \mathrm{C}$ with shaking speed of $180 \mathrm{rpm}$. Samples were taken at $0,2,4,6,8$, 10,15 and $20 \mathrm{~min}$ post-inoculation and centrifuged at $5000 \times \mathrm{g}$ for $10 \mathrm{~min}$ at $4{ }^{\circ} \mathrm{C}$. Phage titers in the supernatant were measured by using the double-layer agar plate method. The experiment was repeated three times.

The influence of temperature and $\mathrm{pH}$ on the adsorption of the phage was monitored. The phage was mixed with 117-T6 at the optimal MOI of 0.001 as above and incubated 2 min at $0,10,20,29,40$ and $45^{\circ} \mathrm{C}$, respectively, with triplicates, and then centrifuged at $5000 \times g$ for $10 \mathrm{~min}$ at $4{ }^{\circ} \mathrm{C}$. The phage was mixed with 117-T6 at the optimal MOI of 0.001 as above at $29^{\circ} \mathrm{C}$ at the $\mathrm{pH}$ of $4,5,6,7,8$ and 9 , respectively, with triplicates, and then centrifuged at $5000 \times g$ for $10 \mathrm{~min}$ at $4{ }^{\circ} \mathrm{C}$. Phage titers in the supernatant were measured by using the double-layer agar plate method. The experiment was repeated three times.

\subsection{One-Step Growth Experiment}

Phage Yong-XC31 was mixed with 117-T6 $\left(1.36 \times 10^{8} \mathrm{CFU} / \mathrm{mL}\right)$ at a MOI of 0.001 with triplicate and allowed to adsorb for $2 \mathrm{~min}$ at $29^{\circ} \mathrm{C}$. Then, centrifuged at $6000 \times g$ for $10 \mathrm{~min}$. Pellets containing the infected cells were washed twice and re-suspended in $40 \mathrm{~mL}$ of fresh NB seawater medium, incubated at $29{ }^{\circ} \mathrm{C}$ with shaking at $220 \mathrm{rpm}$. Samples were taken at $0,10,20,30,40,50,60,90,120,150,180$ and $210 \mathrm{~min}$, respectively, centrifuged at $5000 \times g$ for $10 \mathrm{~min}$ at $4{ }^{\circ} \mathrm{C}$, and then phage titers in the supernatant were immediately determined by the double-layer agar method. Titer measurements were conducted in triplicate.

\subsection{Host Range Determination}

The host range of Yong-XC31 was tested against 34 bacterial strains including the indicator host (Table 1) using the spot test according to the references [25,26]. Cultures of each bacterial strain $\left(10^{8} \mathrm{CFU} / \mathrm{mL}\right)$ were mixed with melted $0.7 \%$ agar $\left(43^{\circ} \mathrm{C}\right) \mathrm{NB}$ seawater medium, respectively, with triplicates and poured on a $1.5 \%$ solid agar to make double layer agar plates. After solidification, $5 \mu \mathrm{L}$ of phage suspensions $\left(10^{6} \mathrm{PFU} / \mathrm{mL}\right)$ were 
spotted on each plate. The plates were cultured at $29^{\circ} \mathrm{C}$ for $8 \mathrm{~h}$. It was considered as positive for clear lysis zones or plaques on the bacteria lawn.

Table 1. Bacterial strains used in the host range assay and infection results.

\begin{tabular}{cccc}
\hline No. Bacteria Strains & Lytic Ability & No. Bacteria Strains & Lytic Ability \\
\hline Vibrio mediterranei 117-T6 & + & Escherichia coli $\mathrm{DH} 5 \alpha$ & - \\
Vibrio hispanicus XXY & - & Citrobacter freundii & - \\
Vibrio fluvialis XXY1 & - & Shewanella putrefaciens & - \\
Vibrio unlnificus XXY & - & Streptococcus iniae & - \\
Vibrio fluvialis XXY2 & - & Alternate pseudomonas XY & - \\
Vibrio parahaemolyticus 1A08161 & - & Shigella dysenteriae & - \\
Vibrio parahaemolyticus 1A11655 & - & Proteus vulgaris & - \\
Vibrio alginolyticus LDF & - & Proteus mirabilis & - \\
Vibrio alginolyticus XY & - & Aeromonas hydrophila & - \\
Vibrio alginolyticus WY & - & Shigella sonnei & - \\
Vibrio alginolyticus SZT & - & Pseudomonas aeruginosa LDF & - \\
Vibrio harveyi $1-5$ & - & Pseudomonas aeruginosa SZT & - \\
Vibrio harveyi LDF & Aeromonas sobria LY-23 & - \\
Vibrio pacinii XY & - & Aeromonas sobria ATCC43979 & - \\
Vibrio anguillarum & - & Pseudoalteromonas issachenkonii XY & - \\
Aeromonas bivalvium XXY & - & Salmonella paratyphi $B$ & - \\
Edwardsiella tarda SZT & - & Enterobacter cloacae & - \\
Edwardsiella tarda LW & - & Marinomonas sp.XY & - \\
Enterobacter sakazakii & - & Pseudomonas sp. XXY & - \\
\hline
\end{tabular}

(+) representative infection, (-) representative non-infection.

\subsection{Genome Extraction and Sequencing}

Genomic DNA of phage Yong-XC31 was extracted utilizing the modified method of standard phenol-chloroform extraction [27]. DNase I and RNase A (TransGen Biotech, Beijing, China) to a final concentration of $1 \mu \mathrm{g} / \mathrm{mL}$ were added to the purified phage YongXC31 stock solution. The mixture was incubated at $37^{\circ} \mathrm{C}$ for $2 \mathrm{~h}$ to remove contaminating bacterial DNA and RNA. DNase I was deactivated by incubating the solution for $15 \mathrm{~min}$ at $80{ }^{\circ} \mathrm{C}$. After adding EDTA to a final concentration of $20 \mathrm{mM}$, proteinase $\mathrm{K}$ at $50 \mu \mathrm{g} / \mathrm{mL}$, and sodium dodecyl sulfate at $0.5 \%(w / v)$, the mixture was incubated for $1 \mathrm{~h}$ at $56{ }^{\circ} \mathrm{C}$. An equal volume of phenol was added to extract the viral DNA, followed by centrifugation at $10,000 \times \mathrm{g}$ for $10 \mathrm{~min}$. The aqueous layer was moved to a fresh tube, to which an equal volume of phenol-chloroform-isoamyl alcohol (25:24:1) was added and mixed, and then centrifuged at $10,000 \times g$ for $10 \mathrm{~min}$. The aqueous layer was mixed with isovolumic chloroform and centrifuged $10,000 \times g$ for $5 \mathrm{~min}$. The aqueous phase was added with an equal volume of isopropanol, stored at $-20^{\circ} \mathrm{C}$ for $3 \mathrm{~h}$, and centrifuged at $4{ }^{\circ} \mathrm{C}$ at $13,000 \times g$ for $20 \mathrm{~min}$. The precipitated DNA was washed with 75\% ethanol. The obtained Yong-XC31 DNA was resuspended in deionized water and stored at $-20^{\circ} \mathrm{C}$ for further experiments.

The NEBNext Ultra II DNA Library Prep Kit for Illumina (\#E7645) was used for constructing genomic library. Genome sequencing of the phage was performed using the Illumina MiSeq (SanDiego, CA, USA) sequencing platform to obtain $2 \times 300$ bp paired-end reads. Low-quality $(\mathrm{Q}-\mathrm{value}<20)$ reads and adapters were filtered out using fastp. SPAdes 3.13.0 software (http:/ / cab.spbu.ru/software/spades/, accessed on 30 December 2020) was utilized to assemble the trimmed reads. Phage genome termini were analyzed using our proposed method [28].

\subsection{Genome Annotation and Taxonomic Analyses}

ORFs prediction was initially conducted with RAST (http:/ / www.rast.nmpdr.org, accessed on 30 December 2020), and then identified with HMMER and HHpred web server $[29,30]$. All predicted ORFs were manually verified using the BLAST tool of NCBI (https: / blast.ncbi.nlm.nih.gov/, accessed on 30 December 2020). tRNAscan-SE was used to search for tRNA genes (http:/ / lowelab.ucsc.edu/tRNAscan-SE/, accessed on 30 December 2020; [31]), and the antibiotic resistance genes and virulence factors were searched in CARD 
database (http: / / arpcard.mcmaster.ca, accessed on 30 December 2020) and VFDB database (http:/ / www.mgc.ac.Cn/VFs/main.htm, accessed on 30 December 2020), respectively.

Nucleotide sequence comparisons were firstly conducted using NCBI BLASTn [32]. The pair-wise average nucleotide identity (ANI) values between the giant phage YongXC31 and the phages with the 10 top highest homology (Table 2) in BLASTn comparison (e-value $<10^{-5}$ ) were confirmed using OrthoANI [33]. The in silico DNA-DNA hybridization (isDDH) values between Yong-XC31 and these closely related giant phages were performed using GGDC (formula 2) [34]. The percentage of conserved proteins (POCP) values between Yong-XC31 and these related giant phages were calculated as described previously [35]. Genome comparison of Yong-XC31 and the closest related phage BONAISHI was done by a genome comparison visualizer, Easyfig [36]. To estimate the nucleotide sequence similarity between Yong-XC31 and other phages in current (26 January 2021) public databases, the Pairwise Sequence Comparison (PASC) classification tool [37] (https://www.ncbi.nlm.nih.gov/sutils/pasc/viridty.cgi, accessed on 30 December 2020) was used. ViPTree online [38] (available at https: / / www.genome.jp / viptree/, accessed on 30 December 2020) was used to generate a proteomic tree based on genome wide sequence similarities, computed by tBLASTx, gathering 56 classified phages of the nine families of Caudovirales, Yong-XC31 and 10 giant phages in Table 2.

Table 2. Average nucleotide identity (ANI), in silico DNA-DNA hybridization (isDDH) and percentage of conserved proteins (POCP) values between Vibrio phage Yong-XC31 and the giant phages with the 10 top highest homology in BLASTn comparison (e-value $<10^{-5}$ ).

\begin{tabular}{ccccc}
\hline Strain & Accession no. & ANI, \% & isDDH, \% & POCP, $\%$ \\
\hline Vibrio phage BONAISHI & MH595538 & 58.65 & 0 & 6.774 \\
Aeromonas phage phiAS5 & HM452126 & 0 & 0 & 0.606 \\
Aeromonas phage CC2 & JX123262 & 0 & 0 & 0.268 \\
Aeromonas phage AS-yj & MF498774 & 0 & 0 & 0.278 \\
Aeromonas phage AS-szw & MF498773 & 0 & 0 & 0.273 \\
Aeromonas phage AS-zj & MF448340 & 0 & 0 & 0.272 \\
Aeromonas phage AS-sw & MF498775 & 0 & 0 & 0.271 \\
Pseudomonas phage Phabio & MF042360 & 0 & 0 & 0.26 \\
Vibrio phage 2.275.O._10N.286.54.E11 & MG592671 & 0 & 0 & 0.245 \\
Vibrio phage 2 TSL-2019 & MF063068 & 0 & 0 & 0 \\
\hline
\end{tabular}

\subsection{Genome Sequence Accession Number}

The complete genome sequence of Vibrio phage Yong-XC31 is available from GenBank under nucleotide accession number MK308674. The phage has been deposited in China General Microbiological Culture Collection Center under number CGMCC No. 17098.

\section{Results}

\subsection{Antibiotic Susceptibility of V. mediterranei 117-T6}

$V$. mediterranei 117-T6 was resistant to 4 of 17 tested antibiotics, which were penicillin G, aboren, polymyxin and clindamycin, respectively (Figure 1). It was intermediate to azithromycin, vancomycin and gentamicin. Though, causing inhibition zones on $V$. mediterranei 117-T6 lawn, amoxicillin, rifampicin, tobramycin, tetracycline, doxycycline, chloramphenicol, ofloxacin and selectrin were not effective inhibitors to $V$. mediterranei 117-T6 as bacterial colonies existing in the inhibition zone of these antibiotics. Bacterium resistant to three or more antimicrobials was defined as multidrug resistant (MDR) $[39,40]$. $V$. mediterranei 117-T6 is a typical multidrug resistant bacterium.

\subsection{Phage Morphology}

Vibrio phage Yong-XC31 produced transparent circular plaques with clear and regular edges on V. mediterranei lawns (Figure 2a). Yong-XC31 is large in size having a head with icosahedral approximately spherical structure, about $113 \mathrm{~nm}$ in diameter, and a contractible tail, about $219 \mathrm{~nm}$ in length (Figure 2b). 


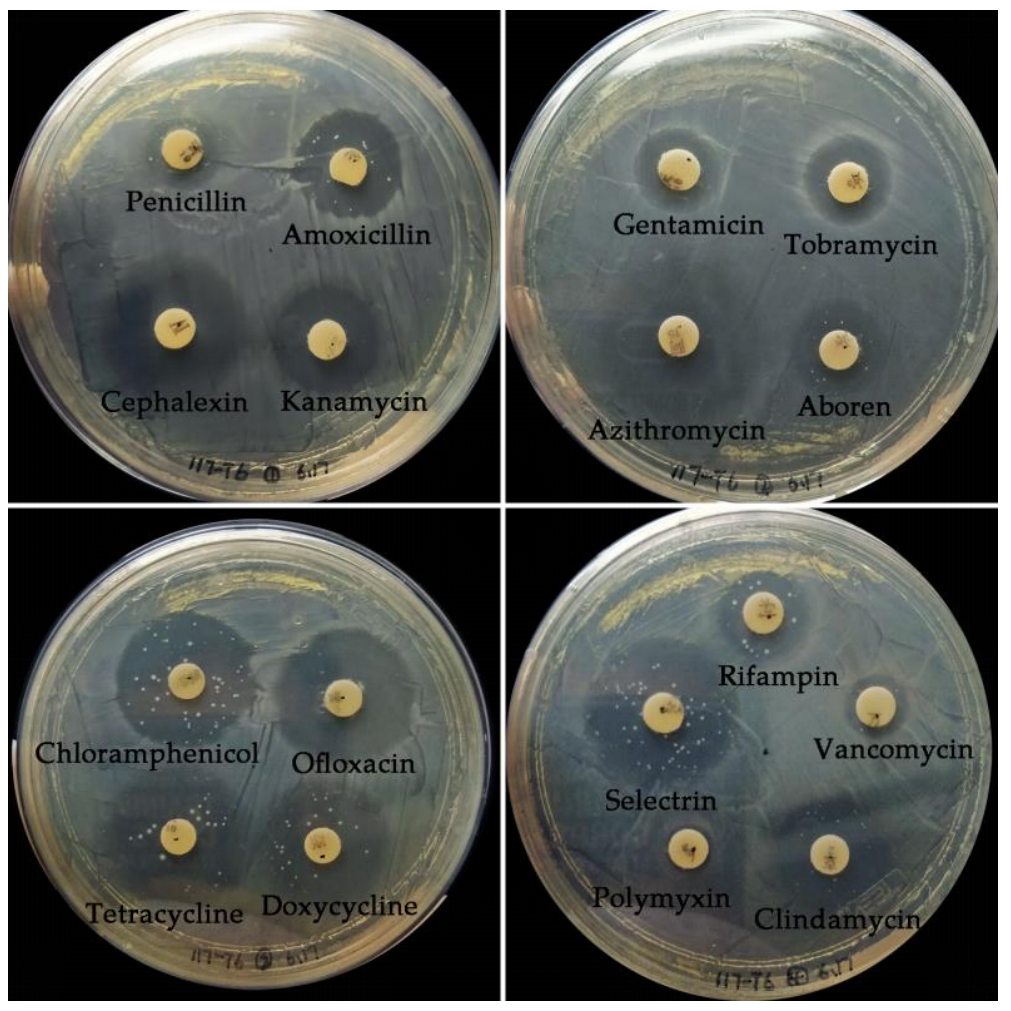

Figure 1. Results of antibiotic susceptibility test. The size of the inhibition zone indicates the susceptibility of bacteria to antibiotics following the standard of the Clinical \& Laboratory Standards Institute (CLSI).

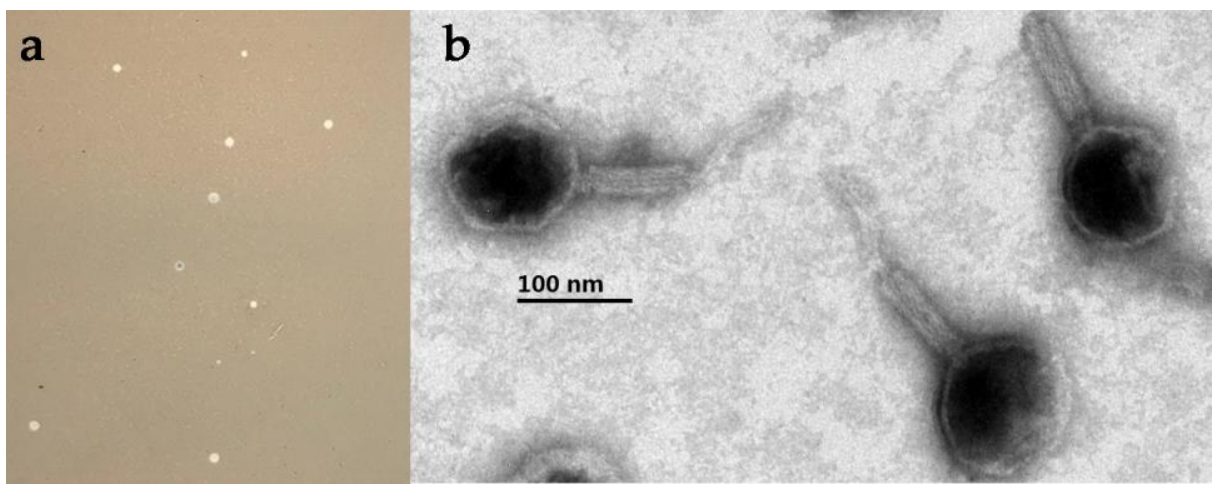

Figure 2. Morphology of the plaque and Vibrio phage Yong-XC31. (a) plaque produced by Yong-XC31 on V. mediterranei lawn; (b) electron micrograph of Yong-XC31. Bar represents $100 \mathrm{~nm}$.

\subsection{Thermal and $p H$ Stability}

Temperature and $\mathrm{pH}$ stability provide more latent capacity with regard to phage storage, transport and potential applications. In the thermal and $\mathrm{pH}$ stability assays, YongXC31 was very stable at $40{ }^{\circ} \mathrm{C}$ maintaining constant titer for over $3 \mathrm{~h}$, relatively stable at $50^{\circ} \mathrm{C}$ and $60^{\circ} \mathrm{C}$ (Figure 3a). The phage was stable at pH 5 to 8 . Although the titer declined dramatically at $\mathrm{pH} 2,10$ and 11 (Figure $3 \mathrm{~b}$ ), Yong-XC31 can tolerate a $\mathrm{pH}$ ranging from 2-4 and 9-10 for at least two hours without complete loss of infectivity.

\subsection{Optimal MOI and Factors Influencing Adsorption}

Among all the tested MOIs, the optimal MOI is 0.001 , when mixing $7.5 \times 10^{5} \mathrm{PFU}$ of Yong-XC31 with $7.5 \times 10^{8} \mathrm{CFU} 117-\mathrm{T} 6$ host cells (Figure 4a). 

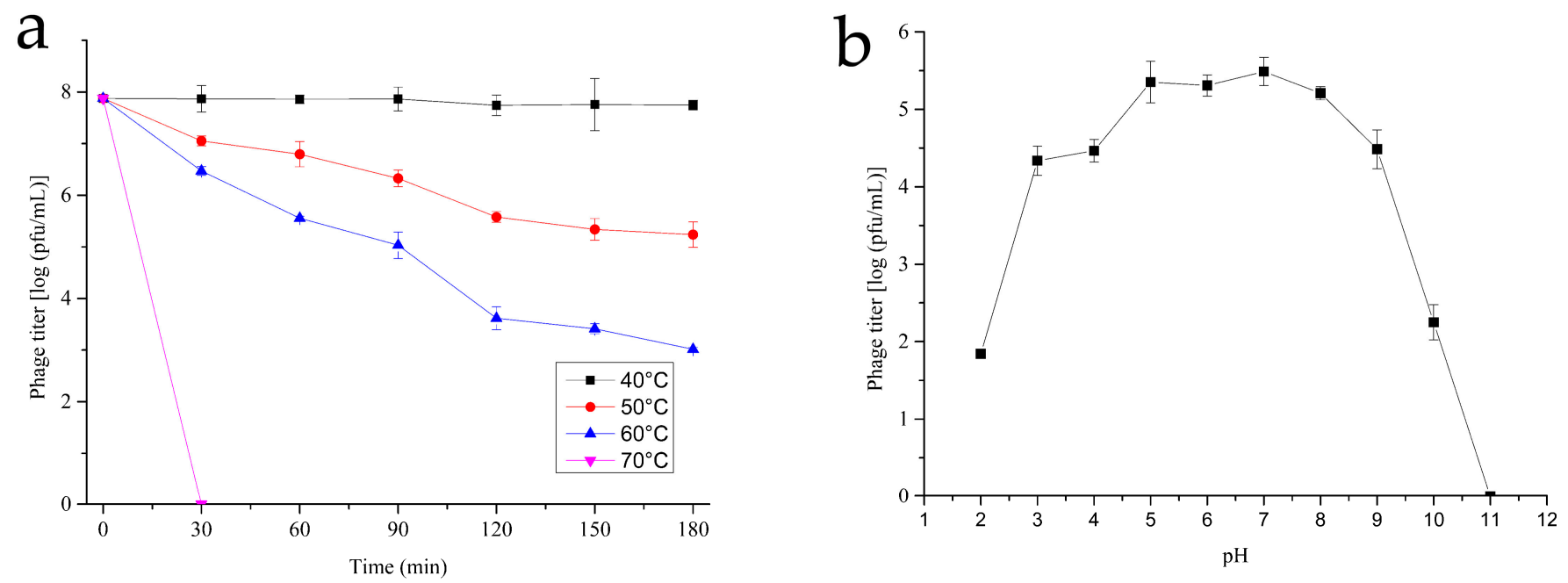

Figure 3. Thermostability (a) and pH stability (b) of Vibrio phage Yong-XC31. All the experiments were conducted in triplicates.
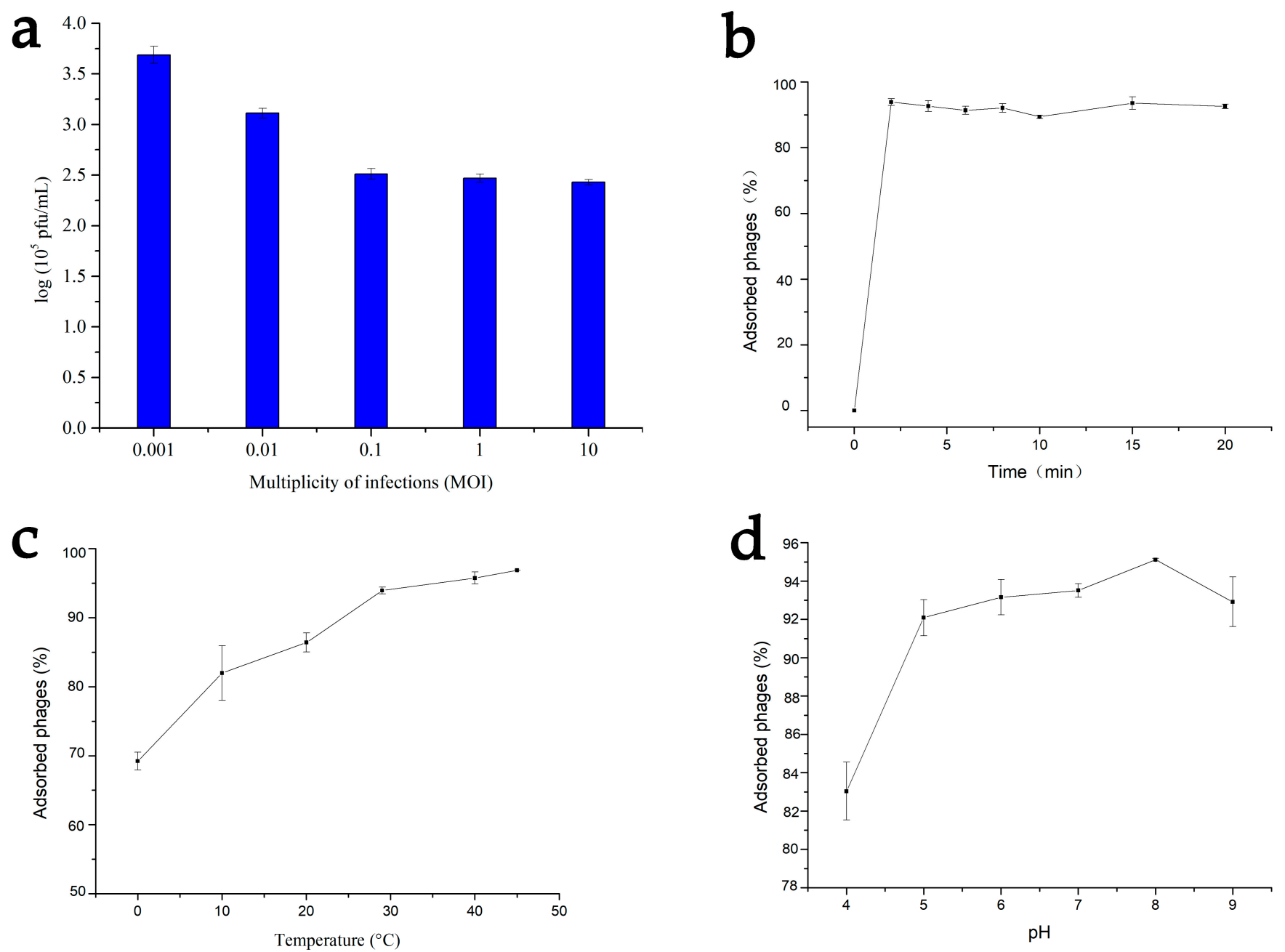

Figure 4. Multiplicities of infection (MOIs) curve (a), temporary adsorption kinetics of Vibrio phage Yong-XC31 (b), influence of temperature on adsorption kinetics (c), and influence of $\mathrm{pH}$ on adsorption kinetics (d). All the experiments were conducted with triplicates. 
Adsorption is a key stage in virus recognition of a sensitive host cell. Adsorption of Yong-XC31 to V. mediterranei 117-T6 is very efficient. The adsorption rate can reach $93.8 \%$ in 2 min at $29^{\circ} \mathrm{C}$ (Figure 4 b). External conditions such as temperature and $\mathrm{pH}$ are influential to phage adsorption, in turn, affect potential applications. From 0 to $50^{\circ} \mathrm{C}$, the adsorption rate of Yong-XC31 to $V$. mediterranei 117-T6 increases with the increase of temperature (Figure 4c). From $\mathrm{pH} 4-8$, the adsorption rate increases with the increase of $\mathrm{pH}$, while decreased at $\mathrm{pH} 9$ (Figure $4 \mathrm{~d}$ ).

\subsection{One-Step Growth Curve}

The one-step growth curve of Yong-XC31 showed a latent period of about $30 \mathrm{~min}$. There are two generally accepted methods for calculating phage burst size. The average burst size of Yong-XC31 was 64,227 calculated as the ratio of mean yield of phage particles liberated to the mean phage particles that infected the bacteria in the latent period (Figure 5) referring to reference [41], and $2 \mathrm{PFU} /$ cell calculated as the ration of the final count of liberated phage particles to the initial count of infected bacterial cells at the beginning of the latent period (Figure 5) referring to reference [24].

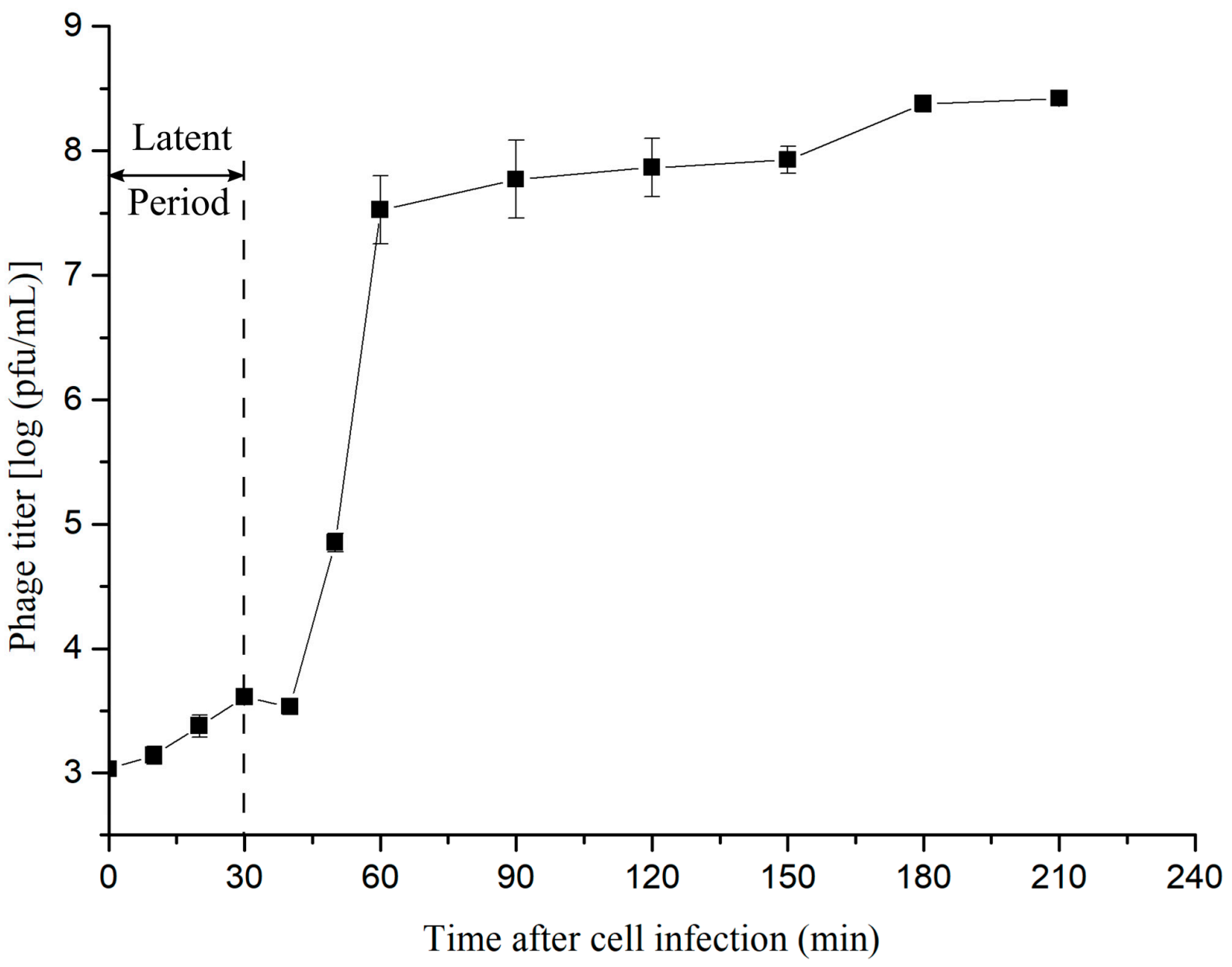

Figure 5. One-step growth curve. All the experiments were conducted at MOI $=0.001$ with triplicates.

\subsection{Host Range Determination}

To test Yong-XC31 host range, 34 different bacterial strains (Table 1) were used employing spot test method. Among these bacterial strains, only V. mediterranei 117-T6 was found to be susceptible to phage Yong-XC31. Yong-XC31 showed strict host specificity, which may be favorable for the application of the phage as it is difficult to change the normal flora. 


\subsection{Genome Analysis of Yong-XC31}

Yong-XC31 is a typical giant phage at genome level. Complete genome sequencing was conducted using next-generation sequencing (NGS) with an average read length of 284.6 bases. $81.66 \%$ of the sequencing reads were matched to the complete genome $(133,281$ out of 163,212 reads) with an average sequencing depth of 130.6-fold. The complete genome of Yong-XC31 is 290,532 bp long with a G + C content of $45.87 \%$. Yong-XC31 genome is unique sharing the highest BLASTn homology with the most related phage BONAISHI (sequence ID: MH595538, query cover as low as 1\%, identity $70.62 \%$ ). $25.2 \%$ predicted Yong-XC31 ORFs might encode novel proteins as they have no similarity to protein sequences in current public databases (26 January 2021).

No tRNA gene was found in the genome. Among the 318 ORFs of Yong-XC31, 17.3\% were predicted functions, $82.7 \%$ predicted as hypothetical proteins. No ORFs associated with virulence factors, toxins or antibiotic resistance genes were found among the annotated ones within Yong-XC31 genome. The predicted ORFs could be classified into five functional categories, including DNA replication/regulation, bacteriophage packaging, bacteriophage structure, lysis and hypothetical protein (Figure 6, Supplement Table S1).

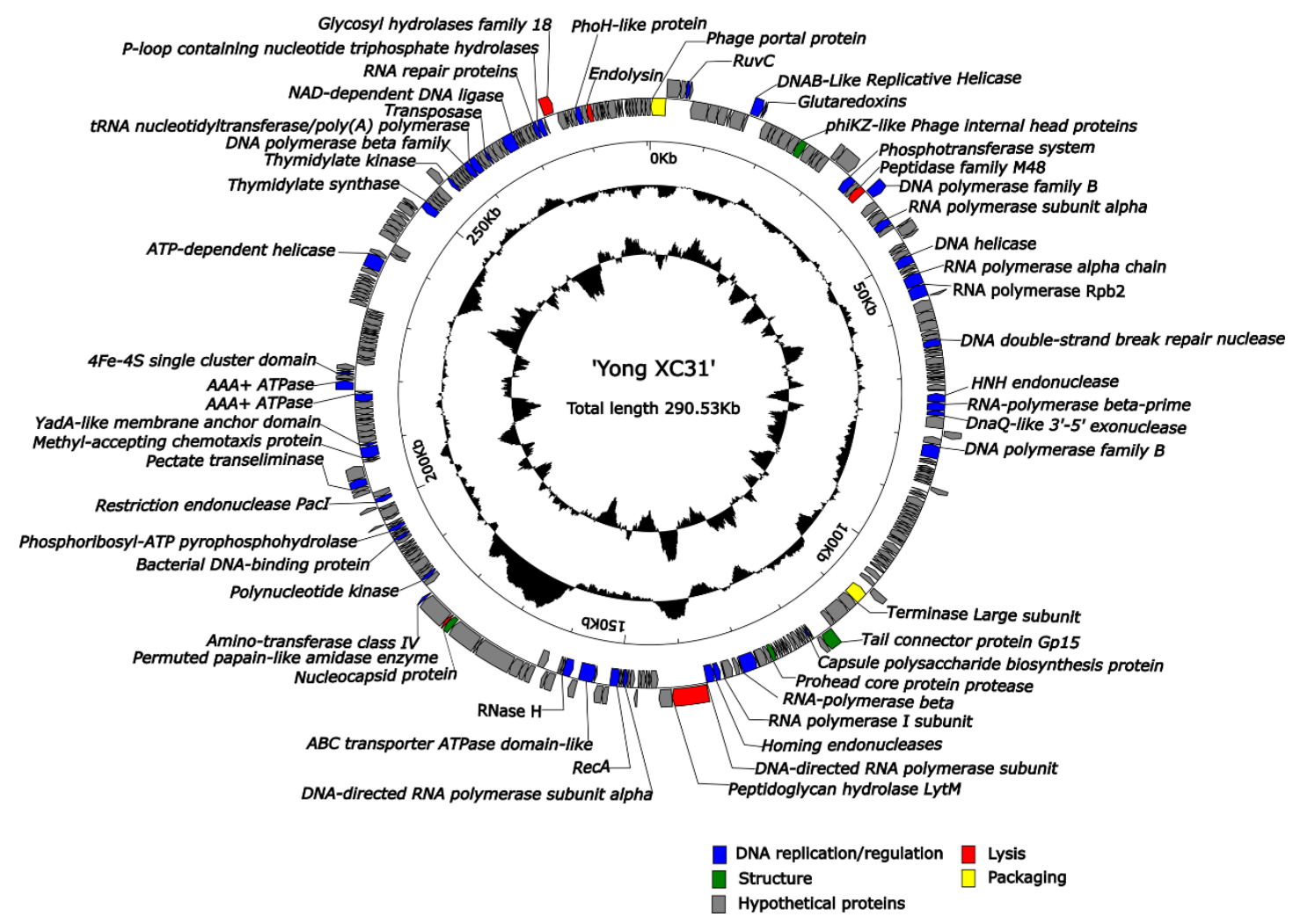

Figure 6. Genome map of Vibrio phage Yong-XC31. The arrow indicates the coding protein sequence, the protein function is distinguished by color, red stands for lysis, yellow for packaging, blue for DNA replication/regulation and green for structure, gray indicates hypothetical protein.

6 ORFs were annotated as structural and assembly genes (Supplement Table S1). 15 ORFs were annotated to be involved in DNA replication, recombination, and repair. 2 ORFs encode homing endonucleases of HNH family (ORF68 and ORF141), one of which is an intron-encoded homing endonuclease (ORF141) located between genes encoding subunits of RNAP.

As mentioned in the introduction, giant bacteriophages commonly contain many genes that do not exist in the small genome bacteriophages. Notably, Yong-XC31 harbours multiple enzyme genes related to bacteriolysis. At least 5 ORFs predicted to play a role in host cell lysis, including a peptidase (family M48, ORF29), a permuted papain-like amidase 
enzyme (ORF175), a glycosyl hydrolases (family 18, ORF295), a peptidoglycan hydrolase LytM (ORF143) and a lysin (ORF302). Remarkably, the lysin has a modular structure comprising an N-terminal glycoside hydrolase 19 domain, and a C-terminal peptidoglycan binding domain (PGBD).

As introduction described, some giant phages contain additional genes which may replace the function of the host proteins, thereby reducing the dependence of giant phages on their bacterial host. Noticeably, Yong-XC31 harbours eight paralogous genes (ORF34, ORF46, ORF47, ORF69, ORF136, ORF140, ORF142, ORF153) for RNAP. In particular, Yong-XC31 harbours genes (ORF265 and ORF271) encoding thymidylate synthase (dTMP synthase) and thymidylate kinase (TdR kinase) responsible for the de novo biosynthesis of thymidylate (dTMP) and as the salvage enzyme which leads to the production of $\mathrm{dTMP}$ even in presence of dTMP synthase inhibition [42]. Yong-XC31 also harbours a gene (ORF278) encoding tRNA nucleotidyltransferase/poly(A) polymerase participating translation, ribosomal structure and biogenesis [43].

\subsection{Taxonomy}

Yong-XC31 is a novel phage. As described above, Yong-XC31 shared the highest BLASTn identity $(70.62 \%)$ with the closest related phage BONAISHI, with the query cover as low as $1 \%$. Only 8 genes were found to be conserved in Yong-XC31 and Vibrio phage BONAISHI by the comparison of Yong-XC31 and Vibrio phage BONAISHI (Figure 7).

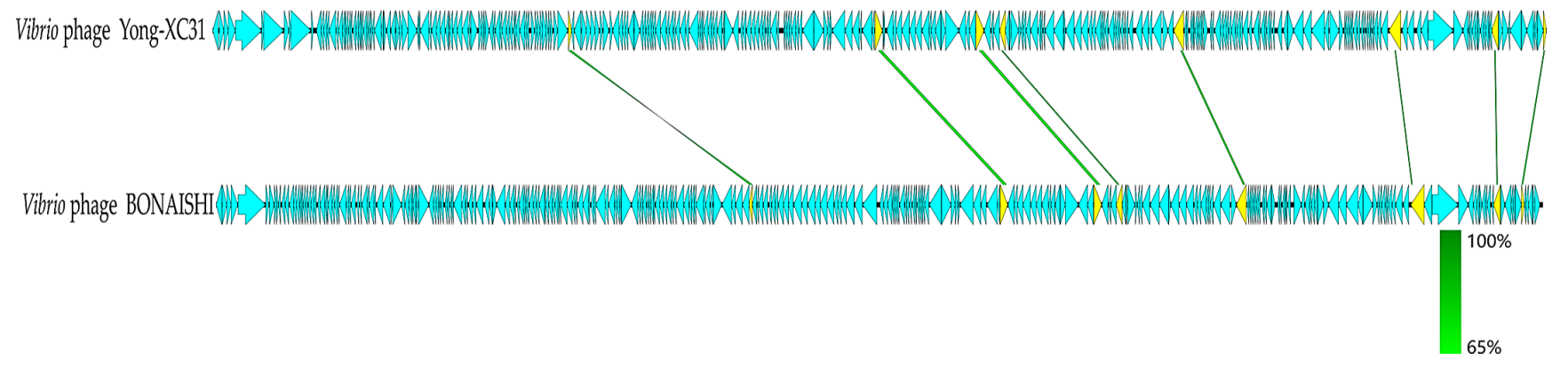

Figure 7. Genome comparison of Vibrio phage Yong-XC31 and the most closely related phage BONAISHI. Strain-specific protein coding genes are shown in light blue, protein coding genes conserved in Yong-XC31 and Vibrio phage BONAISHI are shown in yellow.

Further, the genome of Yong-XC31 shared only 0-58.65\% ANI values with the giant phages with the 10 top highest homology in BLASTn comparison (e-value $<10^{-5}$ ) (Table 2), which are substantially below the $\geq 95 \%$ ANI boundaries to define a species [44,45]. The isDDH values between Yong-XC31 and these giant phages all were 0 , lower than the $70 \%$ cut off to define a species [34]. The POCP values between Yong-XC31 and giant phage species were $0.26-6.77 \%$, much lower than the genus boundary cut-off of $50 \%$.

In addition, the Bacterial and Archaeal Viruses Subcommittee (BAVS) within the International Committee on the Taxonomy of Viruses (ICTV), which holds the responsibility of classifying new prokaryotic viruses, recently redefined a genus as a cohesive group of viruses sharing a $>50 \%$ of high degree of nucleotide sequence similarity [45,46]. YongXC31 shared the highest nucleotide sequence similarity, as low as $11.71 \%$, with the closest related phage in PASC [37] search. It's much below the $>50 \%$ boundaries to define a genus. Summarily, these results indicate the status of Yong-XC31 as a taxonomically unique phage presenting a novel monophyletic genus.

Most jumbo phages were attributed to the Myoviridae family. Yet, in the proteomic tree constructed based on genome wide sequence similarities (Figure 8), Yong-XC31 and three unclassified giant phages clustered in a monophyletic clade independently between the family Drexlerviridae and Herelleviridae. These four giant phages harbor genomes of 242,446-309,157 bp. A new phage family is proposed in Caudovirales order. 


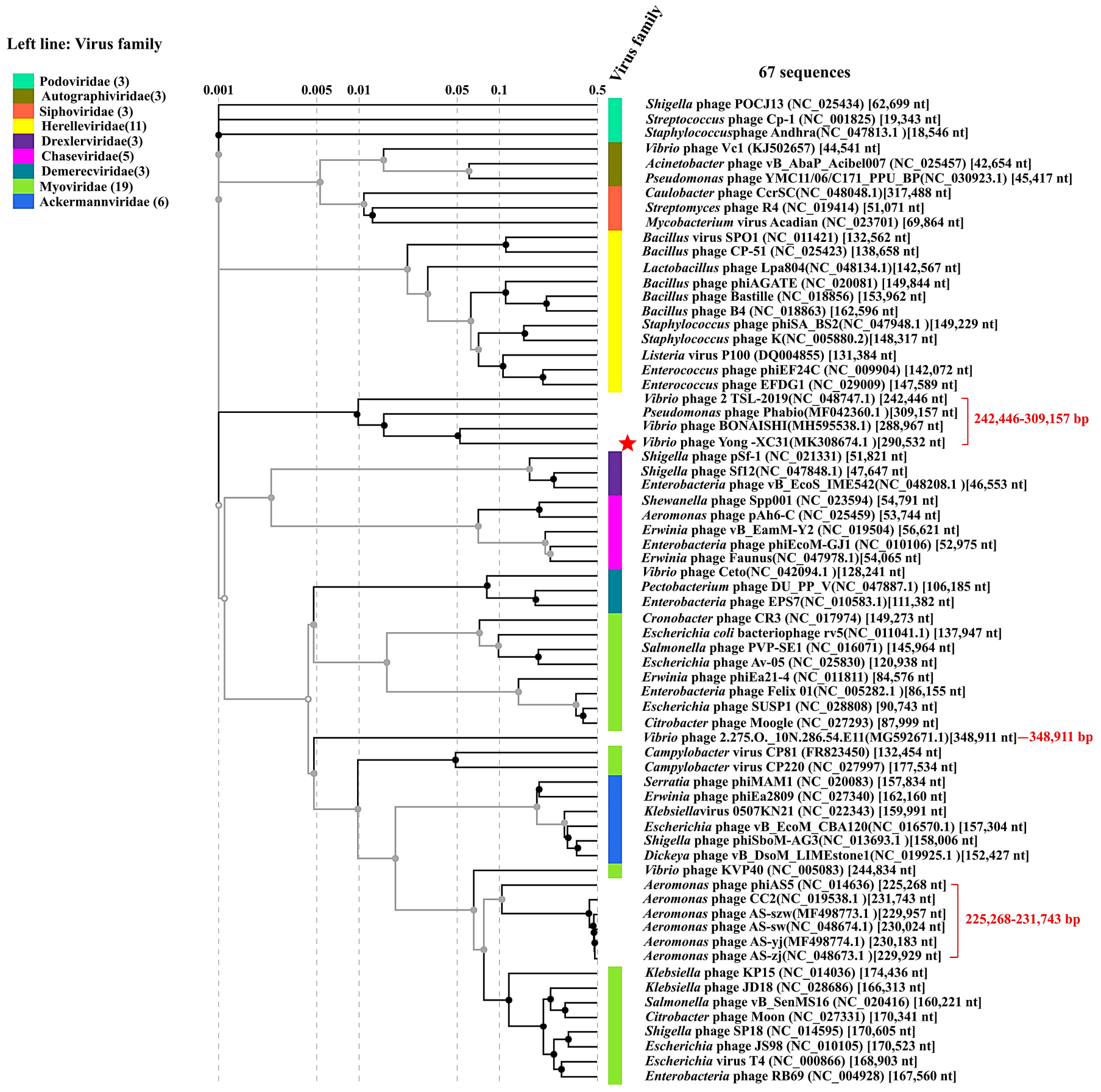

Figure 8. The proteomic tree is generated using ViPTree online based on genome-wide similarities determined by tBLASTx. 56 type species of nine families belonging to the order Caudovirales, Vibrio phage Yong-XC31, and 10 giant phages in Table 2 were included in the analysis. Bacteriophage family assignments according to the official ICTV classification are provided with different color bars. No color bar is marked to unclassified giant phages. Red star refers to Yong-XC31. The sizes or size ranges of the giant phage genomes are shown in red font on the right.

\section{Discussion}

Pyropia is an important cultivated seaweed in Northeast Asia [7,47]. In recent years, increase in the prevalence of diseases and pests has caused a subsequent reduction in their quantity and commercial value $[47,48]$. Among these diseases, yellow spot disease (YSD) is a destructive disease of the conchocelis sporeling culture of Pyropia $[7,47,48]$. V. mediterranei 117-T6 (CGMCC1.16311) was pathogenic to the YSD of conchocelis of several 
Pyropia species [8]. Traditional antibiotic therapy has no stable effect on YSD [49]. In this study, antibiotic susceptibility test demonstrated that $V$. mediterranei 117-T6 was multidrug resistant, which accord with the ineffective antibiotic treatment. Therefore, the development of new tools and strategies to control pathogens and treat diseased Pyropia is becoming a most important issue.

Phages are currently emerging as potential treatments for multidrug resistant bacterial infections. Yet, literature search yielded no information about $V$. mediterranei phage. In this study, the first $V$. mediterranei phage was isolated and identified as a novel giant phage representing a novel phage genus. Proteomic tree indicates that Yong-XC31 together with giant Vibrio phage BONAISHI, Vibrio phage 2 TSL-2019 and Pseudomonas phage Phabio represent a new evolutionary lineage independently between the family Drexlerviridae and Herelleviridae. The four giant phages all infect Gram-negative bacteria, contain genome of 242,446-309,157 bp with only an average $1 / 4$ of the predicted genes being assigned functions. A new family is proposed here in Caudovirales. In the novel proposed family, Yong-XC31 presents a monophyletic genus in consideration of the pair-wise ANI, isDDH, POCP and PASC values.

The therapeutic value of a candidate bacteriophage relies on the characterization of viral properties such as stability, growth kinetics, host range and viral yield [50]. Results of this study indicated that the temperature and $\mathrm{pH}$ stability of Yong-XC31 was good, which is conducive to its application to control $V$. mediterranei infections in complex environment. Results also demonstrated other good properties of Yong-XC31 including a very low optimal MOI (0.001), efficient adsorption to host (reach 93.8\% adsorption rate in only 2 $\mathrm{min})$, a short latent period $(30 \mathrm{~min})$, a high burst size $(64,227)$ and strict host specificity. Additionally, our small-scale laboratory experiments proved that Yong-XC31 could protect both the free-living conchocelis (FLC) and the shell-borne conchocelis (SBC) of Pyropia from harm caused by $V$. mediterranei [49]. These results suggest significant application potential of Yong-XC31 in Pyropia production.

Thus, far, only fourteen jumbo phages infecting Vibrio bacteria have been characterized. Among them, Yong-XC31 is most related to the unclassified phage BONAISHI, which is strictly lytic for several strains of $V$. coralliilyticus pathogenic to coral [50]. Yong-XC31 and BONAISHI share several special characteristics. Their genomes are both about of $290 \mathrm{~kb}$, contain more than one paralogous gene encoding RNAPs and do not harbour identified tRNA gene.

Most phages rely on RNAPs of a bacterial host to transcribe their genes [51]. A strategy used by some phages is to depend on their own single-subunit RNAPs to transcribe a subset of viral genes [52]. An even more radical strategy is used by some giant phage, not need to rely on the host RNAP, yet only relies on self-encoded phage multi-subunit RNAPs: virion-associated RNAPs and early expressed RNAPs [14]. These RNAPs can perform two functions. The virion-associated RNAP is injected into the host cell together with phage DNA and transcribes early phage genes [53]. The early expressed RNAP formed by putative RNAP subunits which would transcribe viral genes expressed in the middle and late stages of infection [54]. This study finds that Yong-XC31 contains five genes encoding virion-associated RNAPs (ORF34, ORF136, ORF140, ORF142, ORF153) and three early expressed RNAPs (ORF46, ORF47, ORF69). This may be beneficial to its efficient infection. In addition, the absence of detectable tRNA in phage BONAISHI genome suggests that it is well adapted to the translation machinery of its hosts, which is a critical process for efficient phage propagation [50]. Similarly, we did not find any tRNA in the genome of Yong-XC31.

As mentioned above, alternative therapies must be developed to mitigate the sharp increase in antibiotic resistance. Besides phage itself, novel antimicrobial strategies include enzyme-based antibiotics ("enzybiotics") such as phage lytic enzymes. Yong-XC31 harbors multiple (at least eight) enzyme genes related to bacteriolysis. These enzyme genes may be potential beneficial resources. 
Very little is known about the processes of host-phage interaction in marine environments. Bailey et al., found that Synechococcus phage S-PM2 contain genes encode homologs of the key photosystem II reaction center core polypeptides (D1 and D2) and proposed that this might play an active role in protecting their hosts against photoinhibition, thereby ensuring an energy supply for replication by preventing the deleterious effects on host cell integrity seen during acute photoinhibition [55]. Phages infecting marine picocyanobacteria often carry a $p s b A$ gene, which encodes a homolog to the photosynthetic reaction center protein, D1. Bragg et al., proposed that phage encoded D1 may help to maintain photosynthesis during the lytic cycle, which in turn could bolster the production of deoxynucleoside triphosphates (dNTPs) for phage genome replication [56]. They examined the contribution of phage $p s b A$ expression to phage genome replication under constant low irradiance and predicted that phage $p s b A$ expression could lead to an increase in the number of phage genomes produced during a lytic cycle of between 2.5 and $4.5 \%$ [56]. In this study, Yong-XC31 possesses unusual genes rarely present in other phages. In particular, Yong-XC31 contains an ORF encoding Methyl-accepting chemotaxis protein (MCP) and a gene encoding EIIB belonging phosphotransferase system. As the predominant chemoreceptor and signal transducer in bacteria and archaea, MCPs also termed transducer-like proteins (Tlps), serve as sensors in bacterial chemotactic signaling [57]. MCPs sense intracellular and environmental signals, and relay them to the downstream signaling pathways in the cytoplasm. Then, bacteria utilize the well-known chemotactic responses to move towards factors that favor survival [58]. Further studies are needed to find whether the expression of the viral methyl-accepting chemotaxis protein gene may enhance the host survival and persistence in the complex environment, thus profiting the phage itself. The phosphoenol phosphotransferase system (PTS) is a multi-component signal transduction cascade that regulates diverse aspects of bacterial cellular physiology in response to the availability of high-energy sugars in the environment [59]. In bacteria, there are often many different EIIs. EIIs are responsible for the phosphorylation of the carbohydrate as well as its transportation across the bacterial membrane [60]. The significance of gene encoding EIIB in Yong-XC31 remains to be studied.

\section{Conclusions}

In conclusion, Vibrio phage Yong-XC31 was isolated and characterized as a new potential biocontrol strategy to control Vibrio mediterranei. A total of 80 orphan ORFs in Yong-XC31 may be a new resource of applications. Giant phage Yong-XC31 has very unique genome sequence. Blast search results, ANI values, isDDH values, $\mathrm{POCP}$ values, nucleotide sequence similarity estimated via PASC and proteomic tree demonstrated Yong-XC31 as a singleton phage distantly related to previously sequenced bacteriophages, representing a new evolutionary lineage of phage. We propose a new phage family with Yong-XC31 as the representative specie of a genus. This study expands the diversity of phages.

\section{Patents}

Lihua Xu; Dengfeng Li; Jing Fang et al., A virulent phage vB_VmeM-Yong XC31 of Vibrio mediterranei and its application (ZL201910792955.8).

Supplementary Materials: The following are available online at https:/ / www.mdpi.com/2076-341 7/11/4/1602/s1.

Author Contributions: D.L., L.X. and Y.T. designed the research. L.X., D.L., Y.T., J.F., R.Y., W.Q., W.L. (Wei Lin), L.P. and W.L. (Wencai Liu) performed the research. L.X. \& D.L. analyzed data and wrote the paper. All authors have read and agreed to the published version of the manuscript.

Funding: This research was funded by the national key research and development program (2018YFA 0903000); the open fund of key laboratory of marine biogenetic resources of State Oceanic Administration (HY201602), the Public Welfare Science and Technology Plan of Ningbo (202002N3039) and sponsored by K.C. Wong Magna Fund of Ningbo University; National Natural Science Foundation of China (31772871) 
Institutional Review Board Statement: Ethical review and approval were not applicable for studies not involving humans or animals.

Informed Consent Statement: Not applicable for studies not involving humans.

Data Availability Statement: Data is contained within the article.

Acknowledgments: We are very grateful for high quality technical support provided by PingPing Zhan of the Electron Microscopy Laboratory of Ningbo University.

Conflicts of Interest: The authors declare no conflict of interest. All authors have seen the manuscript and approved to submit to your journal. To the best of our knowledge, this manuscript has not been published in whole or in part nor is it being considered for publication elsewhere.

\section{References}

1. Ben-Haim, Y.; Rosenberg, E. Vibrio coralliilyticus sp. nov., a temperature-dependent pathogen of the coral Pocillopora damicornis. Int. J. Syst. Evol. Microbiol. 2003, 53, 309-315. [CrossRef]

2. Pang, L.; Zhang, X.H.; Zhong, Y.; Chen, J.; Li, Y.; Austin, B. Identification of Vibrio harveyi using PCR amplification of the toxR gene. Lett. Appl. Microbiol. 2006, 43, 249-255. [CrossRef] [PubMed]

3. Romalde, J.L.; Dieguez, A.L.; Lasa, A.; Balboa, S. New Vibrio species associated to molluscan microbiota: A review. Front. Microbiol. 2014, 4, e413. [CrossRef] [PubMed]

4. Goudenège, D.; Travers, M.A.; Lemire, A.; Petton, B.; Haffner, P.; Labreuche, Y.; Tourbiez, D.; Mangenot, S. A single regulatory gene is sufficient to alter Vibrio aestuarianus pathogenicity in oysters. Environ. Microbiol. 2015, 17, 4189-4199. [CrossRef] [PubMed]

5. Rubio-Portillo, E.; Yarza, P.; Penalver, C.; Ramos-Esplá, A.A.; Anton, J. New insights into Oculina patagonica coral diseases and their associated Vibrio spp. communities. ISME J. 2014, 8, 1794-1807. [CrossRef] [PubMed]

6. Serrano, W.; Tarazona, U.I.; Olaechea, R.M.; Friedrich, M.W. Draft genome sequence of a new Vibrio strain with the potential to produce bacteriocin-like inhibitory substances, isolated from the gut microflora of scallop (Argopecten purpuratus). Genome Announc. 2018, 6, e00419-18. [CrossRef]

7. Liu, Q.Q.; Xu, M.Y.; He, Y.Y.; Tao, Z.; Yang, R.; Chen, H.M. Complete genome sequence of Vibrio mediterranei 117-T6, a potentially pathogenic bacterium isolated from the conchocelis of Pyropia spp. Microbiol. Resour. Announc. 2019, 8, e01569-01518. [CrossRef] [PubMed]

8. Xu, M.Y.; Yang, R.; Liu, Q.Q.; He, Y.Y.; Chen, H.M. Study on yellow spot disease in Pyropia species infected by Vibrio mediterranei 117-T6. J. Fish. China 2020, 44, 1-11. [CrossRef]

9. Wang, X.L.; He, L.W.; Ma, Y.C.; Huan, L.; Wang, Y.Q.; Xia, B.M.; Wang, G.C. Economically important red algae resources along the Chinese coast: History, status, and prospects for their utilization. Algal Res. 2020, 46, 101817. [CrossRef]

10. Baker-Austin, C.; Trinanes, J.A.; Taylor, N.G.H.; Hartnell, R.; Siitonen, A.; Martinez-Urtaza, J. Emerging Vibrio risk at high latitudes in response to ocean warming. Nat. Clim. Chang. 2013, 3, 73-77. [CrossRef]

11. Vezzulli, L.; Grande, C.; Reid, P.C.; Hélaouët, P.; Edwards, M.; Höfle, M.G.; Brettar, I.; Colwell, R.R.; Pruzzo, C. Climate infuence on Vibrio and associated human diseases during the past half-century in the coastal North Atlantic. Proc. Natl. Acad. Sci. USA 2016, 113, E5062-E5071. [CrossRef]

12. Suttle, C.A. Marine viruses-major players in the global ecosystem. Nat. Rev. Microbio. 2007, 5, 801-812. [CrossRef] [PubMed]

13. Breitbart, M.; Bonnain, C.; Malki, K.; Sawaya, N.A. Phage puppet masters of the marine microbial realm. Nat. Microbiol. 2018, 3, 754-766. [CrossRef] [PubMed]

14. Yuan, Y.H.; Gao, M.Y. Jumbo bacteriophages: An overview. Front. Microbiol. 2017, 8, 403. [CrossRef]

15. Hendrix, R.W. Jumbo bacteriophages. Curr. Top. Microbiol. Immunol. 2009, 328, 229-240. [CrossRef]

16. Gorski, A.; Miedzybrodzki, R.; Łobocka, M.; Glowackarutkowska, A.; Bednarek, A.; Borysowski, J.; Jonczykmatysiak, E.; Łusiakszelachowska, M.; Weberdąbrowska, B.; Baginska, N.J.V. Phage therapy: What have we learned? Viruses 2018, 10, 288. [CrossRef] [PubMed]

17. Moye, Z.D.; Woolston, J.; Sulakvelidze, A. Bacteriophage applications for food production and processing. Viruses 2018, 10, 205. [CrossRef]

18. Dy, R.L.; Rigano, L.A.; Fineran, P.C. Phage-based biocontrol strategies and their application in agriculture and aquaculture. Biochem. Soc. Trans. 2018, 46, 1605-1613. [CrossRef] [PubMed]

19. Jamal, M.; Bukhari, S.M.A.U.S.; Andleeb, S.; Ali, M.; Raza, S.; Nawaz, M.A.; Hussain, T.; Rahman, S.U.; Shah, S.S.A. Bacteriophages: An overview of the control strategies against multiple bacterial infections in different fields. J. Basic Microbiol. 2019, 59, 123-133. [CrossRef]

20. Van Etten, J.L.; Lane, L.C.; Dunigan, D.D. DNA viruses: The really big ones (Giruses). Annu. Rev. Microbiol. 2010, 64, 83-99. [CrossRef]

21. Wang, Y.H.; Barton, M.; Elliott, L.; Li, X.X.; Abraham, S.; O’Dea, M.; Munro, J. Bacteriophage therapy for the control of Vibrio harveyi in greenlip abalone (Haliotis laevigata). Aquaculture 2017, 473, 251-258. [CrossRef] 
22. Prada-Peñaranda, C.; Salazar, M.; Güiza, L.; Pérez, M.I.; Leidy, C.; Vives-Florez, M.J. Phage preparation FBL1 prevents Bacillus licheniformis biofilm, bacterium responsible for the mortality of the Pacific white shrimp Litopenaeus vannamei. Aquaculture 2018, 484, 160-167. [CrossRef]

23. Jun, J.W.; Kim, J.H.; Shin, S.P.; Han, J.E.; Chai, J.Y.; Park, S.C. Protective effects of the Aeromonas phages pAh1-C and pAh6-C against mass mortality of the cyprinid loach (Misgurnus anguillicaudatus) caused by Aeromonas hydrophila. Aquaculture 2013, 416, 289-295. [CrossRef]

24. Zhang, Q.; Xing, S.Z.; Sun, Q.; Pei, G.Q.; Cheng, S.; Liu, Y.Y.; An, X.P.; Zhang, X.L.L.; Qu, Y.G.; Tong, Y.G. Characterization and complete genome sequence analysis of a novel virulent Siphoviridae phage against Staphylococcus aureus isolated from bovine mastitis in Xinjiang, China. Virus Genes 2017, 53, 464-476. [CrossRef] [PubMed]

25. Nikapitiya, C.; Dananjaya, S.H.S.; Chandrarathna, H.P.S.U.; Senevirathne, A.; De Zoysa, M.; Lee, J. Isolation and characterization of multidrug resistance Aeromonas salmonicida subsp. Salmonicida and its infecting novel phage ASP-1 from goldfish (Carassius auratus). Indian J. Microbiol. 2019, 59, 161-170. [CrossRef]

26. Adams, M.H. Bacteriophages; Interscience Publishers Inc.: New York, NY, USA; London, UK, 1959.

27. Lu, S.G.; Le, S.; Tan, Y.L.; Zhu, J.M.; Li, M.; Rao, X.C.; Zou, L.Y.; Li, S.; Wang, J.; Jin, X.L.; et al. Genomic and proteomic analyses of the terminally redundant genome of the Pseudomonas aeruginosa phage PaP1: Establishment of genus PaP1-like phages. PLoS ONE 2013, 8, e62933. [CrossRef]

28. Zhang, X.L.L.; Wang, Y.H.; Li, S.S.; An, X.P.; Pei, G.Q.; Huang, Y.; Fan, H.; Mi, Z.Q.; Zhang, Z.Y.; Wang, W.; et al. A novel termini analysis theory using HTS data alone for the identification of Enterococcus phage EF4-like genome termini. BMC Genom. 2015, 16, 1-11. [CrossRef]

29. Finn, R.D.; Clements, J.; Eddy, S.R. HMMER web server: Interactive sequence similarity searching. Nucleic Acids Res. 2011, 39, W29-W37. [CrossRef]

30. Söding, J.; Biegert, A.; Lupas, A.N. The HHpred interactive server for protein homology detection and structure prediction. Nucleic Acids Res. 2005, 33, W244-W248. [CrossRef]

31. Lowe, T.M.; Eddy, S.R. tRNAscan-SE: A program for improved detection of transfer RNA genes in genomic sequence. Nucleic Acids Res. 1997, 25, 955-964. [CrossRef]

32. Johnson, M.; Zaretskaya, I.; Raytselis, Y.; Merezhuk, Y.; McGinnis, S.; Madden, T.L. NCBI BLAST: A better web interface. Nucleic Acids Res. 2008, 36, W5-W9. [CrossRef] [PubMed]

33. Lee, I.; Kim, Y.O.; Park, S.C.; Chun, J. OrthoANI: An improved algorithm and software for calculating average nucleotide identity. Int. J. Syst. Evol. Microbiol. 2016, 66, 1100-1103. [CrossRef] [PubMed]

34. Meier-Kolthoff, J.P.; Auch, A.F.; Klenk, H.P.; Göker, M. Genome sequence-based species delimitation with confidence intervals and improved distance functions. BMC Bioinform. 2013, 14, 60. [CrossRef] [PubMed]

35. Qin, Q.L.; Xie, B.B.; Zhang, X.Y.; Chen, X.L.; Zhou, B.C.; Zhou, J.; Oren, A.; Zhang, Y.Z. A proposed genus boundary for the prokaryotes based on genomic insights. J. Bacteriol. 2014, 196, 2210-2215. [CrossRef]

36. Sullivan, M.J.; Petty, N.K.; Beatson, S.A. Easyfig: A genome comparison visualizer. Bioinformatics 2011, 27, 1009-1010. [CrossRef]

37. Bao, Y.; Chetvernin, V.; Tatusova, T. Improvements to pairwise sequence comparison (PASC): A genome-based web tool for virus classification. Arch. Virol. 2014, 159, 3293-3304. [CrossRef]

38. Nishimura, Y.; Yoshida, T.; Kuronishi, M.; Uehara, H.; Ogata, H.; Goto, S. ViPTree: The viral proteomic tree server. Bioinformatics 2017, 33, 2379-2380. [CrossRef] [PubMed]

39. Magiorakos, A.P.; Srinivasan, A.; Carey, R.B.; Carmeli, Y.; Falagas, M.E.; Giske, C.G.; Harbarth, S.; Hindler, J.F.; Kahlmeter, G.; Olsson-Liljequist, B.; et al. Multidrug-resistant, extensively drug-resistant and pandrug-resistant bacteria: An international expert proposal for interim standard definitions for acquired resistance. Clin. Microbiol. Infect. 2012, 18, 268-281. [CrossRef]

40. Mupfunya, C.R.; Qekwana, D.N.; Naidoo, V. Antimicrobial use practices and resistance in indicator bacteria in communal cattle in the Mnisi community, Mpumalanga, South Africa. Vet. Med. Sci. 2020. [CrossRef]

41. Walakira, J.K.; Carrias, A.A.; Hossain, M.J.; Jones, E.; Terhune, J.S.; Liles, M.R. Identification and characterization of bacteriophages specific to the catfish pathogen, Edwardsiella ictaluri. J. Appl. Microbiol. 2008, 105, 2133-2142. [CrossRef] [PubMed]

42. Look, K.Y.; Moore, D.H.; Sutton, G.P.; Prajda, N.; Abonyi, M.; Weber, G. Increased thymidine kinase and thymidylate synthase activities in human epithelial ovarian carcinoma. Anticancer Res. 1997, 17, 2353-2356.

43. Reuven, N.B.; Zhou, Z.; Deutscher, M.P. Functional overlap of tRNA nucleotidyltransferase, poly(A) polymerase I, and polynucleotide phosphorylase. J. Biol. Chem. 1997, 272, 33255-33259. [CrossRef] [PubMed]

44. Richter, M.; Rosselló-Móra, R. Shifting the genomic gold standard for the prokaryotic species definition. Proc. Natl. Acad. Sci. USA 2009, 106, 19126-19131. [CrossRef] [PubMed]

45. Adriaenssens, E.M.; Brister, J.R. How to name and classify your phage: An informal guide. Viruses 2017, 9, 70. [CrossRef] [PubMed]

46. Adriaenssens, E.M.; Sullivan, M.B.; Knezevic, P.; van Zyl, L.J.; Sarkar, B.L.; Dutilh, B.E.; Alfenas-Zerbini, P.; Łobocka, M.; Tong, Y.G.; Brister, J.R.; et al. Taxonomy of prokaryotic viruses: 2018-2019 update from the ICTV Bacterial and Archaeal Viruses Subcommittee. Arch. Virol. 2020, 165, 1253-1260. [CrossRef]

47. Yang, R.; Liu, Q.Q.; He, Y.Y.; Tao, Z.; Xu, M.Y.; Luo, Q.J.; Chen, J.J.; Chen, H.M. Isolation and identification of Vibrio mediterranei 117-T6 as a pathogen associated with yellow spot disease of Pyropia (Bangiales, Rhodophyta). Aquaculture 2020, 526, 735372. [CrossRef] 
48. Ward, G.M.; Faisan, J.P., Jr.; Cottier-Cook, E.J.; Gachon, C.; Hurtado, A.Q.; Lim, P.E.; Matoju, I.; iMsuya, F.E.; Bass, D.; Brodie, J. A review of reported seaweed diseases and pests in aquaculture in Asia. J. World Aquac. Soc. 2020, 51, 815-828. [CrossRef]

49. Zhu, J.K.; Xu, M.Y.; Liu, Q.Q.; Li, D.F.; Yang, R.; Chen, H.M. Bacteriophage therapy on the conchocelis of Pyropia haitanensis (Rhodophyta) infected by Vibrio mediterranei 117-T6. Aquaculture 2021, 531, 735853. [CrossRef]

50. Jacquemot, L.; Bettarel, Y.; Monjol, J.; Corre, E.; Halary, S.; Desnues, C.; Bouvier, T.; Ferrier-Pagès, C.; Baudoux, A.C. Therapeutic potential of a new jumbo phage that infects Vibrio coralliilyticus, a widespread coral pathogen. Front. Microbiol. 2018, 9, 2501. [CrossRef]

51. Lavysh, D.; Sokolova, M.; Minakhin, L.; Yakunina, M.; Artamonova, T.; Kozyavkin, S.; Makarova, K.S.; Koonin, E.V.; Severinov, $\mathrm{K}$. The genome of AR9, a giant transducing Bacillus phage encoding two multisubunit RNA polymerases. Virology 2016, 495, 185-196. [CrossRef]

52. Ceyssens, P.J.; Minakhin, L.; Van den Bossche, A.; Yakunina, M.; Klimuk, E.; Blasdel, B.; De Smet, J.; Noben, J.P.; Bläsi, U.; Severinov, K.; et al. Development of giant bacteriophage $\phi K Z$ is independent of the host transcription apparatus. J. Virol. 2014, 88, 10501-10510. [CrossRef]

53. Thomas, J.A.; Weintraub, S.T.; Wu, W.; Winkler, D.C.; Cheng, N.; Steven, A.C.; Black, L.W. Extensive proteolysis of head and inner body proteins by a morphogenetic protease in the giant Pseudomonas aeruginosa phage $\varphi$ KZ. Mol. Microbiol. 2012, 84, 324-339. [CrossRef]

54. Yakunina, M.; Artamonova, T.; Borukhov, S.; Makarova, K.S.; Severinov, K.; Minakhin, L. A non-canonical multisubunit RNA polymerase encoded by a giant bacteriophage. Nucleic Acids Res. 2015, 43, 10411-20104. [CrossRef] [PubMed]

55. Bailey, S.; Clokie, M.R.J.; Millard, A. Cyanophage infection and photoinhibition in marine cyanobacteria. Res. Microbiol. 2004, 155, 720-725. [CrossRef] [PubMed]

56. Bragg, J.G.; Chisholm, S.W. Modeling the fitness consequences of a Cyanophage-encoded photosynthesis gene. PLoS ONE 2008, 3, e3550. [CrossRef] [PubMed]

57. Salah Ud-Din, A.I.M.; Roujeinikova, A. Methyl-accepting chemotaxis proteins: A core sensing element in prokaryotes and archaea. Cell. Mol. Life Sci. 2017, 74, 3293-3303. [CrossRef] [PubMed]

58. He, K.; Bauer, C.E. Chemosensory signaling systems that control bacterial survival. Trends Microbiol. 2014, 22, 389-398. [CrossRef]

59. Pickering, B.S.; Lopilat, J.E.; Smith, D.R.; Watnick, P.I. The transcription factor Mlc promotes Vibrio cholerae biofilm formation through repression of phosphotransferase system components. J. Bacteriol. 2014, 196, 2423-2430. [CrossRef]

60. Shin, D.H. A preliminary X-ray study of a refolded PTS EIIB ${ }^{\text {fruc }}$ protein from Escherichia coli. Protein Pept. Lett. 2008, 15, 630-632. [CrossRef] [PubMed] 